\title{
Australian Journal of Crop Science \\ Hay quality evaluation of summer grass and legume forage monocultures and mixtures grown under irrigated conditions
}

\author{
Heba Sabry Attia Salama*, Mahmoud Mohamed Kamel Zeid \\ Crop Science Department, Faculty of Agriculture, Alexandria University, Alexandria, Egypt
}

\author{
*Corresponding author: heba1942001@yahoo.com
}

\begin{abstract}
The introduction of compatible, persistent, high quality grass-legume mixtures could increase forage quality during the summer season in Egypt. This would greatly support the sustainability of a livestock production system. A two-year field trial was carried out during the summer seasons of 2012 and 2013 at the experimental station of the Faculty of Agriculture, Alexandria University, Egypt. The main aim of the study was to assess the potential of forage cowpea-sudan grass (Vigna unguiculata L. - Sorghum sudanese), and forage cowpea-pearl millet (Vigna unguiculata L. - Pennisetum glaucum L.) mixtures to improve hay quality, utilizing three cuts, when compared with cowpea, sudan grass, and pearl millet as individual crops. Investigated forage quality parameters included dry matter (DM), crude protein (CP), nitrogen-free extract (NFE), and fiber fractions (NDF, ADF, ADL) as \%DM. In addition, the hay quality indices namely, relative feed value (RFV), and relative forage quality (RFQ), derived from the dry matter intake (DMI $\% \mathrm{BW})$, digestible dry mater (DDM \%DM), and total digestible nutrients (TDN \%DM), also were evaluated. Results showed that, in general, the $1^{\text {st }}$ cut was of a higher quality than the $2^{\text {nd }}$ and $3^{\text {rd }}$ cuts, being characterized by highest significant NFE, and also lowest significant NDF and ADL values. However, the DM content increased significantly with the successive cuts. The forage cowpea (FCP) was characterized by its increased $\mathrm{CP}$ content, and thus contributed to increasing the $\mathrm{CP}$ content of the grass-legume mixtures compared to the pure grass plots. Moreover, screening of the tested grass-legume mixtures and monocultures with regard to the hay quality indices revealed that mixing grass and legume forage crops was an effective technique in producing hay of a similar quality to that of the forage legume alone, but better than that of the forage grass alone. The highest RFV value was a characteristic of the FCP stands (Prime), followed by the three grass-legume mixtures (Grade 2), and then the three pure grass stands (Grade 3). Similarly, according to the RFQ grading system, the pure FCP and the three mixtures were graded as "Premium" hay quality, and the three pure grass stands were graded as "Good" hay quality.
\end{abstract}

Keywords: Forages, mixtures, hay grading and quality.

Abbreviations: DM_Dry matter, CP_Crude protein, NFE_Nitrogen free extract, NDF_ Neutral detergent fiber, ADF_Acid detergent fiber, ADL_Acid detergent lignin, RFV_Relative feed value, RFQ_Relative forage quality, DMI_Dry matter intake, DDM_Digestible dry matter, TDN_Total digestible nutrients, BW_Body weight, FCP_Forage cowpea, BSG_Black sudan grass, WSG_White sudan grass, PM_Pearl millet.

\section{Introduction}

The agricultural sector in Egypt has witnessed significant developments over the last two decades which directly affected its role in national income formation and promoting exports. Such developments have also affected farmers' choices as related to the applied cropping system and technology, also levels of income and farmers' response to market changes. Livestock form an important component of the agricultural sector in Egypt, representing about $24.5 \%$ of the agricultural gross domestic product (GDP), with value of around 33.6 billion Egyptian pounds (SADS, 2009). Egypt is known to have little effective precipitation, with the highest of $200 \mathrm{~mm}$ being unequally distributed and in limited areas, which results in poor rangeland, and makes the Egyptian forage production system mainly dependent on irrigation. In the winter season, Egypt depends mainly on Egyptian clover (Trifolium alexandrinum) as the key forage crop (ELNahrawy, 2008a and 2008b). However, the feed shortage peak consistently is during the summer season. Consequently, ruminants in Egypt experience marked seasonal fluctuations in feed supply and pasture quality. This results in a seasonal pattern in the quantity and quality of the produced milk and meat. This problem is largely attributed to the inconsistency of forage production and quality measures throughout the growing season. One strategy that could be adopted to solve this problem during the summer season in Egypt is mixed cropping of some summer grass and legume species, which could provide the livestock with better nutritional options throughout the growing season.

Mixture cropping is an important component of selfsustaining, low-input agricultural systems, traditionally adopted in the Mediterranean region (Adesogan et al., 2002). Its main objective has been to maximize use of resources such as space, light, and nutrients (Zhang and Li, 2003) as well as to improve forage quality and quantity (Ghanbari Bonjar and Lee, 2003; Azraf-ul-Haq et al., 2007; Dahmardeh et al., 2009). Meanwhile, grasses and legumes are considered as important forage crops because of their nutritional value, especially protein content in legumes and crude fiber in grasses (Rakeih et al., 2008). However, monocultures of legumes or grasses do not provide satisfactory results for 
forage production and nutritive value (Osman and Nersoyan, 1986). Thus, mixing legume forages with grass forages can be an effective way to improve forage quality and nutritive value of the end product (Ross et al., 2004; Lithourgidis et al., 2006). Literature also stated that intake of fodder is low when fed as pure fodders, either of legumes or grasses, compared with their grass-legume mixtures (Ansar et al., 2010). The successful mixtures need to be selected from these forage crops that possess compatible maturity and harvesting schemes, complement each other in growth distribution and ecological niche, and do not, severely, compete with each other for growth and life requirements (Holland and Brummer, 1999; Al-Khateeb et al., 2001). Forage cowpea (Vigna unguiculata L.) is said to have originated in Africa, where it has become an integral part of traditional cropping systems, particularly in the semiarid West African savanna (Steele, 1972). As a leguminous forage crop, it is characterized by its high crude protein content (Khan et al., 1987). In addition, it is known to be drought tolerant (Oduor, 2007) and well adapted to water stress, high temperatures and other biotic stresses (Ehlers and Hall, 1997; Dadson et al., 2005). It is, therefore, expected to show satisfactory production and adaptation when grown in Egypt during the summer season. On the other hand, sorghum (Sorghum spp.) is an important forage grass that possesses a wide range of ecological adaptability because of its xerophytic characteristics (Ahmad et al., 2007). Its fodder is fed to almost every class of livestock, and can be used as hay or silage. However, sorghum fodder is poor in quality due to low protein content and presence of hydrocyanic acid (Hingra et al., 1995). Another summer forage grass grown in Egypt is pearl millet (Pennisetum glaucum L.), which is a quickgrowing and short-duration crop, grown for fodder and grain purposes, and characterized by its high tillering potential, drought and heat tolerance, and high dry matter production (Ayub et al., 2007). However, similar to other forage grasses, it has a poor protein content and, alone, can't support a sustainable dairy production system. It is, therefore, imperative to improve the hay quality and quantity of fodder grasses. Mixed cropping especially with forage legumes can improve both hay yield and quality, as legumes are a good source of protein (Moreira, 1989). It is, thus, hypothesized that a successful prospective summer forage grass-legume mixture would be that composed of forage cowpea mixed with sudan grass or pearl millet.

Among the most prominent hay quality indicators are the Relative Feed Value (RFV) and Relative Forage Quality (RFQ). The RFV is a widely used forage quality index that was developed by the Hay Marketing Task Force of the American Forage and Grassland Council - AFGC (Rohweder et al., 1978). It became an important tool in the marketing of forage, and in forage quality education. It has been proven very useful for livestock producers and hay farmers for a long time to price hay and determines the market value of forage (Moore and Undersander, 2002b). Its value has been reported by the National Forage Testing Association (NFTA). RFV is calculated from predicted values for both Dry Matter Intake (DMI) and Digestible Dry Matter (DDM) based on laboratory analyses for neutral detergent fiber (NDF) and acid detergent fiber (ADF), respectively. Despite its advantages, RFV has not been incorporated into nutritional models. The lack of use of RFV by nutritionists may be because DDM is not a conventional measure of available energy requirements and feed energy concentration. Instead, Total Digestible Nutrients (TDN) may have been the first measure of available energy to be adopted for routine use by animal nutritionists. Even though modern energy systems use Net Energy (NE) for maintenance, growth, or lactation, each of the NE measures may be calculated from TDN (NRC, 2001). Therefore, nutritionists would more likely use an index of forage quality if TDN was used to express available energy. A forage quality index using both DM intake and TDN would be compatible with most models. Therefore, Relative Forage Quality (RFQ) was proposed as an alternative quality index for an estimate of voluntary intake of available energy when forage is fed as the sole source of energy and protein. The intake component is DMI (\% BW), as in RFV, and the available energy component is TDN (\% DM). The RFQ incorporated new advances in knowledge and technology into the existing RFV system (Moore and Undersander, 2002a and 2002b). The RFQ index proved to provide a better reflection of grass's higher fiber digestibility and the impact of that on energy and intake potential.

The objective of the current study was to assess the potential of forage cowpea-sudan grass and forage cowpeapearl millet mixtures to improve hay quality, over three cuts, when compared with cowpea, sudan grass, and pearl millet as individual crops. In this paper the forage quality indicators; dry matter, crude protein, nitrogen free extract, and fiber fractions are presented and discussed. In addition, the RFV and RFQ representing the hay quality indices were also evaluated.

\section{Results and Discussion}

Data of the forage quality analysis, including DM, CP, NFE, $\mathrm{NDF}, \mathrm{ADF}$, and ADL contents $\left(\mathrm{g} \mathrm{kg}^{-1}\right)$, as well as the hay quality indices, including DDM (\%DM), DMI (\%BW), TDN (\%DM), RFV, and RFQ, will be presented and discussed. Main effects of the cuts and tested forage treatments will be presented and discussed when the interaction is not significant.

\section{Variations of the forage quality parameters}

Analysis of variance demonstrated highly significant variations among the three tested cuts and the seven forage treatments for DM, NFE, NDF, and ADL $\left(\mathrm{g} \mathrm{kg}^{-1}\right)$ contents. The two-way interaction between the cut and the forage treatment was significant with regard to $\mathrm{CP}$ and $\mathrm{ADF}\left(\mathrm{g} \mathrm{kg}^{-1}\right)$ contents.

\section{Cut-related variations}

Means of the tested parameters as affected by the three cuts are presented in Table 1 . It is clear that the first cut was significantly superior in NFE compared to the advanced cuts. NFE values reached 148.29 against $132.10\left(\mathrm{~g} \mathrm{~kg}^{-1}\right)$ for the $1^{\text {st }}$ and $3^{\text {rd }}$ cuts, respectively. On the other hand, the $3^{\text {rd }}$ cut always had significantly higher levels of DM content and fiber fractions (NDF and ADL), compared to the $1^{\text {st }}$ and $2^{\text {nd }}$ cuts. The difference between the $1^{\text {st }}$ and $3^{\text {rd }}$ cuts amounted to $3.8,4.0$, and $0.3 \%$ for DM, NDF, and ADL, respectively. Reduced leaf-to-stem ratio is a major cause of the decline in forage quality with maturity, and also the loss in quality that occurs under adverse hay-curing conditions. It is known that leaves are higher in quality than stems, and since reproductive growth lowers leaf-to-stem ratio, and thus forage quality, the higher proportion of leaves in forage in the $1^{\text {st }}$ cut, compared to the successive cuts, is usually accompanied by higher quality in terms of higher amounts of NFE and lower amounts of fiber fractions. For the same reason the fiber fractions usually increase with successive cuts. 


\section{Forage-related variations}

Table 2 presents the variations among the seven forage monocultures and mixtures with regard to the tested parameters of forage quality. It was observed that, in general, the BSG and the WSG grown in pure stands had the highest DM, NFE, and NDF values, while the PM pure stands had intermediate values for the three parameters. By contrast, FCP, grown also as monoculture, had the lowest significant values of the three parameters. Mixing FCP with BSG or WSG at 50:50 ratio, resulted in higher DM, NFE, and NDF values compared to pure FCP. On the other hand, the FCP pure stands produced the highest significant ADL content, amounting to $43.88\left(\mathrm{~g} \mathrm{~kg}^{-1}\right)$, while the BSG and PM pure stands produced the lowest significant ADL contents, amounting to 28.47 and $27.93\left(\mathrm{~g} \mathrm{~kg}^{-1}\right)$, respectively. The DM content results confirm that mixing forage grasses with legumes improves the DM content compared to the pure legume stands. Similar results were reported for clover-barley and clover-triticale mixtures (El-Karamany et al., 2012, and 2014) and for maize-cow pea mixtures (Ibrahim et al., 2006). Forage legumes are known to have lower carbohydrate contents than grasses (Waldo and Jorgensen, 1981). Nor ElDin (1978) reported that the NFE content was higher in grass-clover mixtures in comparison with clover monoculture, while the reverse was true for pure grass stands. In his study of forage quality of maize and cowpea intercrops, Dahmardeh et al. (2009) reported that the pure grass stands were significantly superior in water soluble carbohydrates content compared with the pure legume stands and the intercrops. However, the intercrops improved the WSC content compared with the pure legume stands. Comparing legumes to grasses in dairy studies is usually confounded by NDF differences between the two species. Grasses generally contain more NDF, and therefore, when diets are formulated to contain an equal amount of forage $\mathrm{DM}$, the total dietary NDF concentration will be higher for diets containing grasses compared to legumes. Similar results were reported by Lithourgidis et al. (2006) for the oatcommon vetch mixtures, and by Sleugh et al. (2000) for kura clover-intermediate wheat grass mixtures. Caballero et al. (1995) and Laidlaw and Teuber (2001), reported that forage legume monocultures are generally higher in lignin content than forage grass monocultures. This trend for lignin content is most probably because the cell wall of grasses contains less lignin than the cell wall of dicots; thus, legumes have more lignin associated with the fiber (Carpita and McCann, 2000). Crude protein content is one of the very important criteria in forage quality evaluation (Assefa and Ledin, 2001; Lithourgidis et al., 2006). Means of the CP content (Table 4 and Fig. 1) reveal that there was a slight variation in the $\mathrm{CP}$ content among the three cuts, and only in case of the pure FCP stands and the three tested forage mixtures was the $3^{\text {rd }}$ cut significantly inferior in $\mathrm{CP}$ content to the two other cuts. However, a clearer variation was detected among the forage stands, where the pure FCP stand and the three forage mixtures had significantly higher $\mathrm{CP}$ contents than the grass pure stands. Despite the consistency in the direction of the interaction, its magnitude was highly variable, as the differences between the highest value for FCP stands and the lowest value for pure BSG stands were around 7, 6 and $4 \%$ for the $1^{\text {st }}, 2^{\text {nd }}$ and $3^{\text {rd }}$ cuts, respectively. In other words, the difference between the highest and lowest forage treatments in the $\mathrm{CP}$ content was greater and more distinguished for the $1^{\text {st }}$ cut than the $3^{\text {rd }}$ cut. Low protein level in cereal forage is not uncommon. Many researchers mentioned that forage grass monocultures always produced the lowest-significant
$\mathrm{CP}$ content compared to pure legume and legume-grass stands (e.g. Caballero et al., 1995; Giacomini et al., 2003; and Sengul, 2003). However, grasses grown in intercropping with legumes tend to contain a higher percentage of protein than grasses grown alone (Eskandari, 2012). Results of the current study showed that mixing FCP with different grass species produced $\mathrm{CP}$ contents comparable to that produced by the pure FCP, and more than that produced by the pure grass stands. These results are consistent with the results of Carr et al. (1998) and Berdahl et al. (2004). Similarly, Lynch et al. (2004), suggested that the legume component (equal or more than $30 \%$ ) of the binary legume-grass mixture acts as an effective "N-buffer", maintaining forage yield and protein content consistently higher, and within a narrower range, across all treatments. Lithourgidis et al. (2006), and Ibrahim et al. (2006) came to similar conclusions. They found that planting pure forage legume stands, and its mixtures, with the highest seeding rates resulted in the highest protein percentages.

\section{Interaction variations}

The effect of the two-way interaction between the cut and the forage treatment on the ADF content is presented in Table 4, and Fig. 2. The ADF content peaked with the $3^{\text {rd }}$ cut for all the forage treatments except the pure FCP stands. Concerning the seven forage treatments, an obvious significant variation in ADF content was detected; however, again with wider magnitude in the case of the third cut. As expected, the pure forage legume stands produced the lowest ADF content, followed by the forage grass-legume mixtures, the forage grasses recorded the highest ADF contents. Meanwhile, the differences between the highest and lowest ADF contents were around 19,21 , and $23 \%$ for the $1^{\text {st }}, 2^{\text {nd }}$, and $3^{\text {rd }}$ cuts, respectively. These results are in agreement with those obtained by Iskandari (2012).

\section{Variations of the hay quality indices}

The RFV is calculated from predicted values for both DMI and DDM, based on laboratory analyses for NDF and ADF, respectively, and the RFQ is conceptually the same, except that the TDN replaces the DDM in the RFQ calculation. Consequently, the variations among RFV and RFQ take the same trend as the variations among the laboratory parameters from which they were derived. Significant variations in the DMI (\%BW), RFV, and RFQ among the three cuts and the seven forage monocultures and mixtures were detected. In addition, the interaction between the cuts and forage treatments exerted a significant effect on DDM and TDN (\%DM).

\section{Cut-related variations}

Means presented in Table 1 shows that the $1^{\text {st }}$ cut had the highest significant DMI, RFV, and RFQ compared with the $2^{\text {nd }}$ and $3^{\text {rd }}$ cuts, amounting to $2.34 \% \mathrm{DM}, 124.66$, and 191.40 for the three respective parameters. The $3^{\text {rd }}$ cut clearly had the lowest significant records for all the parameters. The fiber content of the plant material is inversely proportional to its RFV and RFQ (Linn and Kuehn, 1994). In their investigation of the forage quality, Ball et al. (2001) found that fiber of leaves is both lower in content and higher in digestibility than fiber of stems; the fact that the $1^{\text {st }}$ cut is characterized by its higher leaf-stem ratio, compared with the subsequent cuts, might contribute in explaining its high RFV and RFQ. 
Table 1. Means of the tested quality parameters for the three cuts.

\begin{tabular}{|c|c|c|c|c|c|c|c|c|c|c|c|}
\hline Cut & $\mathrm{DM}_{\mathrm{gkg}}{ }^{-1}$ & ${\mathrm{CP} \mathrm{gkg}^{-1}}^{-1}$ & NFE gkg $^{-1}$ & $\mathrm{NDF}_{\text {gkg }}{ }^{-1}$ & $\mathrm{ADF}_{\mathrm{gkg}}{ }^{-1}$ & ADL $\mathrm{gkg}^{-1}$ & DDM \%DM & DMI \%BW & TDN \%DM & RFV & RFQ \\
\hline 1 & $207.13 c^{*}$ & $146.02 \mathrm{a}$ & $148.29 \mathrm{a}$ & $532.57 \mathrm{c}$ & $275.69 c$ & $32.25 \mathrm{~b}$ & $67.42 \mathrm{a}$ & $2.34 \mathrm{a}$ & $64.65 \mathrm{a}$ & $124.66 \mathrm{a}$ & $191.40 \mathrm{a}$ \\
\hline 2 & $233.71 \mathrm{~b}$ & $140.88 \mathrm{a}$ & $141.59 \mathrm{~b}$ & $552.27 \mathrm{~b}$ & 291.45 b & $33.41 \mathrm{ab}$ & $66.20 \mathrm{~b}$ & $2.25 \mathrm{~b}$ & $62.83 \mathrm{~b}$ & $117.80 \mathrm{~b}$ & $179.18 \mathrm{~b}$ \\
\hline 3 & $244.96 \mathrm{a}$ & $119.56 \mathrm{~b}$ & $132.10 \mathrm{c}$ & $572.44 \mathrm{a}$ & $311.07 \mathrm{a}$ & $35.08 \mathrm{a}$ & $64.67 \mathrm{c}$ & $2.17 \mathrm{c}$ & $60.68 \mathrm{c}$ & $111.15 \mathrm{c}$ & $167.15 \mathrm{c}$ \\
\hline
\end{tabular}

*Means followed by different small letter within the same column are significantly different according to the L.S.D. test at 0.05 level of probability.

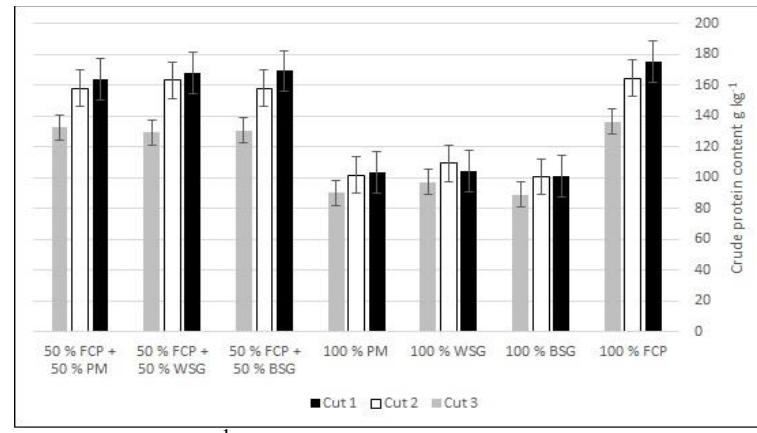

Fig 1. Variations in $\mathrm{CP}$ content $\left(\mathrm{g} \mathrm{kg}^{-1}\right)$ as affected by the interaction between cut and forage treatment

\begin{tabular}{|c|c|c|c|c|c|c|}
\hline Forage Treatment & DM gkg ${ }^{-1}$ & $\mathrm{CP}_{\mathrm{gkg}^{-1}}$ & NFE gkg $^{-1}$ & NDF gkg $^{-1}$ & ADF gkg $^{-1}$ & ${\mathrm{ADL} \mathrm{gkg}^{-1}}^{-1}$ \\
\hline $100 \%$ FCP & $205.99 \mathrm{de}^{*}$ & $158.60 \mathrm{a}$ & $124.10 \mathrm{c}$ & $417.32 \mathrm{f}$ & $180.28 \mathrm{f}$ & $43.88 \mathrm{a}$ \\
\hline $100 \%$ BSG & $250.08 \mathrm{a}$ & $96.80 \mathrm{~b}$ & $150.93 \mathrm{a}$ & $652.16 \mathrm{a}$ & $376.80 \mathrm{~b}$ & $28.47 \mathrm{~d}$ \\
\hline $100 \% \mathrm{WSG}$ & $233.10 \mathrm{~b}$ & $103.57 \mathrm{~b}$ & $143.60 \mathrm{~b}$ & $647.69 \mathrm{a}$ & $392.34 \mathrm{a}$ & $30.74 \mathrm{~cd}$ \\
\hline $100 \%$ PM & $231.53 \mathrm{bc}$ & $98.60 \mathrm{~b}$ & $147.49 \mathrm{ab}$ & $629.29 \mathrm{~b}$ & $355.60 \mathrm{c}$ & $27.93 \mathrm{~d}$ \\
\hline $50 \% \mathrm{FCP}+50 \% \mathrm{BSG}$ & $230.58 \mathrm{bc}$ & $152.63 \mathrm{a}$ & $143.91 \mathrm{ab}$ & $590.39 \mathrm{c}$ & $304.64 \mathrm{~d}$ & $33.79 \mathrm{bc}$ \\
\hline $50 \% \mathrm{FCP}+50 \% \mathrm{WSG}$ & $218.22 \mathrm{~cd}$ & $153.44 \mathrm{a}$ & $144.50 \mathrm{ab}$ & $572.45 \mathrm{~d}$ & $309.14 \mathrm{~d}$ & $33.96 \mathrm{bc}$ \\
\hline $50 \% \mathrm{FCP}+50 \% \mathrm{PM}$ & $199.68 \mathrm{e}$ & $151.51 \mathrm{a}$ & $143.80 \mathrm{ab}$ & $528.34 \mathrm{e}$ & $257.36 \mathrm{e}$ & $34.229 \mathrm{bc}$ \\
\hline
\end{tabular}

*Means followed by different small letter (s) within the same column are significantly different according to the L.S.D. test at 0.05 level of probability.

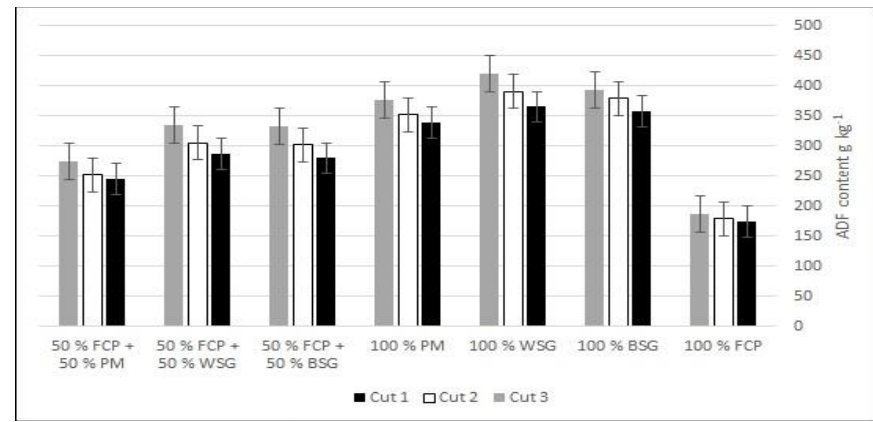

Fig 2. Variations in ADF content $\left(\mathrm{g} \mathrm{kg}^{-1}\right)$ as affected by the interaction between cut and forage treatment. 
Table 3. Means of DDM (\% DM), DMI (\% BW), TDN (\%DM), RFV and RFQ for the seven forage treatments.

\begin{tabular}{llllll}
\hline Forage Treatment & DDM $(\%$ DM) & DMI $(\%$ BW $)$ & TDN $(\%$ DM $)$ & RFV & RFQ \\
\hline $100 \%$ FCP & $74.86 \mathrm{a}^{*}$ & $2.88 \mathrm{a}$ & $75.62 \mathrm{a}$ & $167.25 \mathrm{a}$ & $268.08 \mathrm{a}$ \\
$100 \%$ BSG & $59.55 \mathrm{e}$ & $1.84 \mathrm{~d}$ & $53.02 \mathrm{e}$ & $85.11 \mathrm{de}$ & $120.29 \mathrm{e}$ \\
$100 \%$ WSG & $58.34 \mathrm{f}$ & $1.86 \mathrm{~d}$ & $51.23 \mathrm{f}$ & $83.97 \mathrm{e}$ & $117.09 \mathrm{e}$ \\
$100 \%$ PM & $61.20 \mathrm{~d}$ & $1.91 \mathrm{~d}$ & $55.46 \mathrm{~d}$ & $90.55 \mathrm{~d}$ & $130.22 \mathrm{~d}$ \\
$50 \%$ FCP + 50\% BSG & $65.17 \mathrm{c}$ & $2.03 \mathrm{c}$ & $61.32 \mathrm{c}$ & $102.13 \mathrm{c}$ & $153.72 \mathrm{c}$ \\
$50 \%$ FCP + 50\% WSG & $64.82 \mathrm{c}$ & $2.10 \mathrm{c}$ & $60.80 \mathrm{c}$ & $105.47 \mathrm{c}$ & $157.02 \mathrm{c}$ \\
$50 \%$ FCP + 50\% PM & $68.85 \mathrm{~b}$ & $2.27 \mathrm{~b}$ & $66.76 \mathrm{~b}$ & $121.40 \mathrm{~b}$ & $186.78 \mathrm{~b}$ \\
\hline
\end{tabular}

* Means followed by different small letter within the same column are significantly different according to the L.S.D. test at 0.05 level of probability.

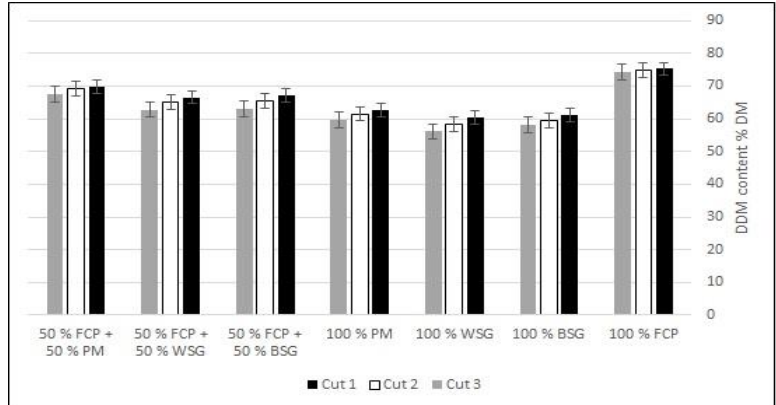

Fig 3. Variations in DDM content (\% DM) as affected by the interaction between cut and forage treatment

Table 4. Means of $\mathrm{CP}$ and $\mathrm{ADF}$ contents $\left(\mathrm{g} \mathrm{kg}^{-1}\right)$ as affected by the interaction between the three cuts and seven forage treatments.

\begin{tabular}{|c|c|c|c|c|c|c|}
\hline \multirow{3}{*}{ Forage Treatment } & \multicolumn{3}{|c|}{$\mathrm{CP} \mathrm{g} \mathrm{kg}^{-1}$} & \multicolumn{3}{|c|}{ ADF $\mathrm{g} \mathrm{kg}^{-1}$} \\
\hline & \multicolumn{3}{|c|}{ Cut } & \multicolumn{3}{|c|}{ Cut } \\
\hline & 1 & 2 & 3 & 1 & 2 & 3 \\
\hline $100 \%$ FCP & $174.96 \mathrm{aA}^{*}$ & $164.63 \mathrm{aA}$ & $136.22 \mathrm{bA}$ & $174.74 \mathrm{aE}$ & $179.67 \mathrm{aE}$ & $186.42 \mathrm{aF}$ \\
\hline $100 \%$ BSG & $100.74 \mathrm{aB}$ & $100.59 \mathrm{aB}$ & $89.08 \mathrm{aB}$ & $357.39 \mathrm{bA}$ & $378.99 \mathrm{aA}$ & $394.02 \mathrm{aB}$ \\
\hline $100 \% \mathrm{WSG}$ & $104.21 \mathrm{aB}$ & $109.38 \mathrm{aB}$ & $97.12 \mathrm{aB}$ & $365.31 \mathrm{cA}$ & $391.07 \mathrm{bA}$ & $420.64 \mathrm{aA}$ \\
\hline $100 \% \mathrm{PM}$ & $103.71 \mathrm{aB}$ & $101.86 \mathrm{aB}$ & $90.22 \mathrm{aB}$ & $338.35 \mathrm{bB}$ & $351.78 \mathrm{bB}$ & $376.66 \mathrm{aC}$ \\
\hline $50 \%$ FCP + 50\% BSG & $169.19 \mathrm{aA}$ & $158.13 \mathrm{aA}$ & $130.59 \mathrm{bA}$ & $279.90 \mathrm{cC}$ & $302.01 \mathrm{bC}$ & $332.01 \mathrm{aD}$ \\
\hline $50 \%$ FCP $+50 \%$ WSG & $167.73 \mathrm{aA}$ & $163.13 \mathrm{aA}$ & $129.45 \mathrm{bA}$ & $286.87 \mathrm{cC}$ & $305.68 \mathrm{bC}$ & $334.88 \mathrm{aD}$ \\
\hline $50 \% \mathrm{FCP}+50 \% \mathrm{PM}$ & $163.88 \mathrm{aA}$ & $158.07 \mathrm{aA}$ & $132.59 \mathrm{bA}$ & $245.82 \mathrm{bD}$ & $251.92 \mathrm{bD}$ & $274.33 \mathrm{aE}$ \\
\hline
\end{tabular}

*Means followed by different small letter within the same row, or different capital letter within the same column for each parameter, are significantly different according to the L.S.D. test at 0.05 level of probability.

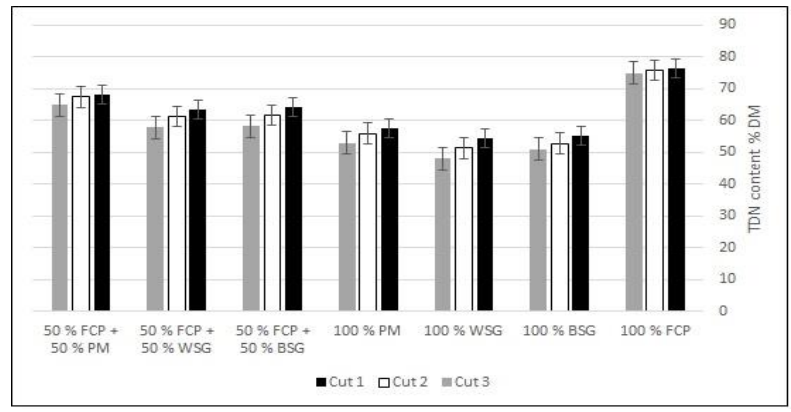

Fig 4. Variations in TDN content (\% DM) as affected by the interaction between cut and forage treatment.

Table 5. Means of DDM and TDN (\% DM), as affected by the interaction between the three cuts and seven forage treatments.

\begin{tabular}{|c|c|c|c|c|c|c|}
\hline \multirow{3}{*}{ Forage Treatment } & \multicolumn{3}{|c|}{ DDM \%DM } & \multicolumn{3}{|c|}{ TDN \%DM } \\
\hline & \multicolumn{3}{|c|}{ Cut } & \multicolumn{3}{|c|}{ Cut } \\
\hline & 1 & 2 & 3 & 1 & 2 & 3 \\
\hline $100 \%$ FCP & $75.29 \mathrm{aA}$ & $74.90 \mathrm{abA}$ & $74.38 \mathrm{aA}$ & $76.26 \mathrm{aA}$ & $75.69 \mathrm{aA}$ & $74.91 \mathrm{aA}$ \\
\hline $100 \%$ BSG & $61.06 \mathrm{aE}$ & $59.38 \mathrm{bE}$ & $58.21 \mathrm{cE}$ & $55.25 \mathrm{aE}$ & $52.76 \mathrm{bE}$ & $51.04 \mathrm{bE}$ \\
\hline $100 \% \mathrm{WSG}$ & $60.44 \mathrm{aE}$ & $58.44 \mathrm{bE}$ & $56.13 \mathrm{cF}$ & $54.34 \mathrm{aE}$ & $51.38 \mathrm{bE}$ & $47.98 \mathrm{cF}$ \\
\hline $100 \%$ PM & $62.54 \mathrm{aD}$ & $61.50 \mathrm{bD}$ & $59.56 \mathrm{cD}$ & $57.44 \mathrm{aD}$ & $55.89 \mathrm{aD}$ & $53.03 \mathrm{bD}$ \\
\hline $50 \% \mathrm{FCP}+50 \% \mathrm{BSG}$ & $67.10 \mathrm{aC}$ & $65.37 \mathrm{bC}$ & $63.04 \mathrm{cC}$ & $64.16 \mathrm{aC}$ & $61.62 \mathrm{bC}$ & $58.17 \mathrm{cC}$ \\
\hline $50 \% \mathrm{FCP}+50 \% \mathrm{WSG}$ & $66.55 \mathrm{aC}$ & $65.09 \mathrm{bC}$ & $62.81 \mathrm{cC}$ & $63.36 \mathrm{aC}$ & $61.20 \mathrm{bC}$ & $57.84 \mathrm{cC}$ \\
\hline $50 \% \mathrm{FCP}+50 \% \mathrm{PM}$ & $69.75 \mathrm{aB}$ & $69.28 \mathrm{aB}$ & $67.53 \mathrm{bB}$ & $68.08 \mathrm{aB}$ & $67.38 \mathrm{aB}$ & $64.80 \mathrm{bB}$ \\
\hline
\end{tabular}

* Means followed by different small letter(s) within the same row, or different capital letter within the same column for each parameter, are significantly different according to the L.S.D. test at 0.05 level of probability. 


\section{Forage-related variations}

Concerning the variations among the seven tested forage monocultures and mixtures, it was observed that the pure FCP stands were superior to the other forage treatments concerning DMI (\%BW), RFV, and RFQ, with values amounting to $2.88 \% \mathrm{DM}, 167.25$, and 268.08 , respectively (Table 3). While the three pure forage grass stands (BSG, WSG, and PM) had the lowest significant values from the three hay quality indicators. The three forage mixtures were intermediate between the pure legume and pure grass stands. Noticeably, the best forage mixture regarding the three parameters was the $50 \% \mathrm{FCP}+50 \% \mathrm{PM}$, with values of 2.27 $\% \mathrm{DM}, 121.40$, and 186.78 for DMI, RFV, and RFQ, respectively. Grasses typically have higher NDF and ADF concentrations and consequently have lower RFV and RFQ. Although the RFQ gives more credit for digestible fiber in grasses, due to the higher fiber contents of grasses compared to legumes, at similar stages of maturity, the hay quality indices (RFV and RFQ) of grasses will be lower (Paulson et al. 2008). According to the AFGC hay quality standards (Marsalis et al. 2009), the seven forage monocultures and mixtures investigated in the current study are categorized with regard to their RFV records into 3 main categories; namely, Prime for the pure FCP stands, Grade 2 for the three forage mixtures, and Grade 3, which characterized the three pure grass treatments. Similarly, the Southern Forage Quality Categorization System (Hancock, 2011) graded the seven forage treatments according to their RFQ values as follows: the pure FCP stands and the three grass-legume mixtures are graded as Premium hay quality, followed by the three pure forage grasses, which are graded as Good hay quality. None of the tested forage treatments was of a Fair or Utility RFQ. Beef cattle producers will primarily find the "Fair" category to be most suitable to dry (non-lactating) stock. When nutritional needs exceed maintenance, those producers should choose hay from the "Good" category and place an emphasis on higher RFQ scores within that range for those livestock classes that are expected to rapidly gain weight or do hard work. In contrast, dairy producers will need to select forage from the "Good" and "Premium" categories, with the "Premium" quality reserved for high-producing dairy cows and young calves. Finally, this categorization system clearly identifies forage (i.e., the Utility category) that is most unlikely to be nutritionally sufficient or result in a costeffective ration. Based on the previous explanation, the three tested grass-legume mixtures were of a similar quality to the pure FCP stands, and will satisfy the nutritional needs of the high-producing dairy cows and young calves in an intensive dairy production system.

\section{Interaction variations}

Means of the DDM and TDN (\%DM), as affected by the twoway interaction, are presented in Table 5, and Figs. 3 and 4, and reveal that the interaction moved almost in the same direction within both parameters. A slight variation was detected among the three cuts, mostly in favor of the $1^{\text {st }}$ or $1^{\text {st }}$ and $2^{\text {nd }}$ cuts. On the other hand, significant variations among the studied forage treatments were detected for both parameters for the three cuts. The best DDM and TDN values were reported for the pure FCP stands, followed by the grasslegume mixtures. The lowest values were recorded for the pure grass stands. However, remarkable shifts in the magnitude of the variation were observed, which might have contributed to the significant interaction. The variation between the highest and lowest forage treatments in the
DDM reached $14.85,16.46$, and $18.25 \%$ DM for the $1^{\text {st }}, 2^{\text {nd }}$, and $3^{\text {rd }}$ cuts, respectively. Similarly, the differences among the three respective cuts in the TDN reached 21.92, 24.31, and $26.93 \% \mathrm{DM}$. The detected variations in the DDM and TDN values clearly were in line with the variations in the $\mathrm{ADF}$ values from which they were calculated.

\section{Materials and Methods}

\section{Experimental site, design, and treatments}

Field experiments were conducted during the summer seasons of the years 2012 and 2013 at the experimental farm of the Faculty of Agriculture, Alexandria University, Alexandria, Egypt.

A split-plot experimental design with three replicates was used to evaluate three successive cuts of one forage legume species namely, forage cowpea (Vigna unguiculata L.), and three forage grass species, white-seed sudan grass (Sorghum sudanese), black-seed sudan grass (Sorghum sudanese), and pearl millet (Pennisetum glaucum L.), sown in monocultures and binary mixtures as follows: $1.100 \%$ pure forage cowpea (FCP), 2. 100\% pure black-seed sudan grass (BSG), 3. 100\% pure white-seed sudan grass (WSG), 4. 100\% pure pearl millet (PM), 5. 50\% FCP + 50\% BSG, 6. 50\% FCP + 50\% $\mathrm{WSG}$, and 7. 50\% FCP + 50\% PM.

All the forage treatments were drilled after the recommended seeding rates of the Egyptian Ministry of Agriculture, amounting to $50 \mathrm{~kg} \mathrm{ha}^{-1}$ for all the tested species.

\section{Management and sampling}

The experimental plots were sown on May 20, 2012, and June 10,2013 . The plot size was $14.4 \mathrm{~m}^{2}$. All plots were treated similarly, i.e. fertilized and harvested three times at the same interval in each growing season. Fertilizer applications were split into three equal applications, applied before the first, second, and third harvests. Broadleaf and grass weeds were hand-removed from plots, and no serious incidence of insects or diseases was observed. First cut was taken at 55 DAS (days after sowing), with a 45-day interval between each two successive cuts. The plots were cut at the optimum maturity stage for hay production, which is the early-bud stage for forage legumes and the boot stage for forage grasses. Plots were manually harvested with a sickle to a 5-cm stubble height. A representative sub-sample of approximately $500 \mathrm{~g}$ fresh matter per plot was dried at $60{ }^{\circ} \mathrm{C}$ to constant weight to determine dry matter (DM) content.

\section{Analytical procedures}

The dried hay sub-samples were uniformly ground to a particle size of 1-mm. The concentrations of neutral detergent fiber (NDF), acid detergent fiber (ADF), and acid detergent lignin (ADL) were determined sequentially, using the semiautomatic ANKOM $^{220}$ Fiber Analyzer (ANKOM Technology, Macedon, NY, USA) as described by Van Soest et al. (1991). The same method was used to determine crude fiber content of the samples that was later used in the calculations. NDF and ADF were analyzed without a heatstable amylase and expressed inclusive of residual ash, while ADL content was corrected after the residual ash content. Ash was determined by combusting the sub-sample in a muffle oven at $550{ }^{\circ} \mathrm{C}$ for $3 \mathrm{~h}$ (AOAC, 2012). Prior to total nitrogen analysis, the dried samples were ground again to a particle size of $10 \mu \mathrm{m}$. Nitrogen content was analyzed using the Kjeldahl procedure (AOAC, 2012), and crude protein 
(CP) content was calculated from the $\mathrm{N}$ content. Crude fat was measured using the Soxhlet apparatus as described in the AOAC (2012). Nitrogen-free extract (NFE) was then obtained by subtraction, i.e. 100-(moisture+crude protein+crude fat+crude fibre+ash). Dry Matter Intake (DMI), as \%BW, was calculated based on the laboratory analyses for NDF. In addition, Digestible Dry Matter (DDM) and Total Digestible Nutrients (TDN), as \%DM, were calculated from the ADF values (NRC, 2001). Finally, Relative Feed Value (RFV) and Relative Forage Quality (RFQ), were calculated as proposed by Rohweder et al. (1978) and Moore and Undersander (2002a and 2002b), respectively.

\section{Statistical analysis}

The three cuts and seven forage treatments were tested for significance using Proc Mixed of SAS 9.1 (SAS Institute, Inc., 2000). Data from the 2012 and 2013 growing seasons are presented in a combined analysis, because the test of homogeneity of variance (Winer, 1971), when performed, revealed that the error of the variance between the two experimental seasons was not significantly different.

Only replicates were considered random. The quality parameter $(Q)$ then was analyzed according to the following model:

$Q_{i j k}=\mu+F_{i}+C_{j}+R_{k}+e_{i j k}+(F x C)_{i j}+s_{i j k}$

where $\mu$ is the overall mean, $F_{i}$ is the forage treatment effect ( $i=1,2,3,4,5,6,7), \mathrm{C}_{j}$ is the cut effect $(j=1,2,3), \mathbf{R}_{k}$ is the replication $(k=1,2,3), \mathrm{e}_{i j k}$ is the effect of main plot, $(\mathrm{F} \times \mathrm{C})_{i j}$ is the effect of the interaction between the forage treatment and the cut, and $\mathrm{s}_{i j k}$ is the effect of sub-plot.

Forage quality analyses and hay quality indices are presented and discussed. Significance was declared at $P<$ 0.05 , and means were compared with the least significant difference (L.S.D) procedure.

\section{Conclusion}

Results of the current study confirmed that mixing grass and legume forage crops was an effective technique in producing hay of a similar quality to that of the forage legume alone, but better than that of the forage grass alone. Under Egyptian agricultural conditions, the pure FCP stands as well as the three tested grass-legume mixtures were similar to each other, and superior to the pure grass stands, in CP concentration. Meanwhile, the tested mixtures, similar to the pure FCP, produced lower NDF and ADF contents than the pure grasses. This was obviously reflected in the resulting RFV and RFQ patterns. The pure FCP and the three mixtures were graded as Prime-Grade 2 and Premium hay quality regarding the RFV and RFQ, respectively. This accomplished grading strongly suggests that these forage treatments are quite suitable for high-producing dairy cows and young calves. This forage mixture approach would greatly and consistently support a sustainable and highly productive livestock feeding system during the summer season in Egypt.

\section{Acknowledgement}

The authors are grateful to Prof. Robert P. Patterson, Department of Crop Science, College of Agriculture and Life Science, North Carolina State University, for revising the written manuscript and improving its language.

\section{References}

Adesogan AT, Salawu MB, Deaville ER (2002) The effect on voluntary feed intake, invivo digestibility and nitrogen balance in sheep of feeding grass silage or pea-wheat intercrops differing in pea to wheat ratio and maturity. Anim Feed Sci Tech. 96(3-4): 161-173.

Ahmad A, Ahmad R, Mahmood N, Tanveer A (2007) Performance of forage sorghum intercropped with forage legumes under different planting patterns. Pak J Bot. 39(2): 431-439.

Al-Khateeb SA, Leilah AA, Al-Thabet SS, Al-Barak KM (2001) Study on mixed sowing of Egyptian clover (Trifolium alexandrinum L.) with ryegrass (Lolium multiflorum Lam.), Barley (Hordeum vulgare L.) and oat (Avena fatua L.) on fodder yield and quality. Egyptian J Appl Sci. 16:159-171.

Ansar M, Ahmed ZI, Malik MA, Nadeem M, Majeed A, Rischkowsky BA (2010) Forage yield and quality potential of winter cereal-vetch mixtures under rainfed conditions. Emir J Food Agric. 22(1): 25-36

AOAC International (2012) Official Methods of Analysis (19 ${ }^{\text {th }}$ Ed.) Association of Official Analytical Chemists. Gaithersburg, MD, USA.

Assefa G, Ledin I (2001) Effect of variety, soil type and fertilizer on the establishment, growth, forage yield, quality and voluntary intake by cattle of oats and vetches cultivated in pure stands and mixtures. Anim Feed Sci Tech. 92:95-111.

Ayub M, Nadeem MA, Tanveer A, Tahir M, Khan RMA (2007) Interactive effect of different nitrogen levels and seeding rates on fodder yield and quality of pearl millet. Pak J Agric Res. 44(4): 592-596.

Azraf-ul-Haq A, Riaz A, Mahmood N (2007) Production potential and quality of mixed sorghum forage under different intercropping systems and planting patterns. Pak J Agric Sci. 44:203-207.

Ball DM, Collins M, Lacefield GD, Martin NP, Mertens DA, Olson KE, Putnam DH, Undersander DJ, Wolf MW (2001) Understanding forage quality. American Farm Bureau Federation Publication 1-01, Park Ridge, Illinois

Berdahl JD, Karn JF, Hendrickson JR (2004) Nutritive quality of cool-season grass monocultures and binary grass-alfalfa mixtures at late harvest. Agron J. 96(4): 951-955.

Caballero R, Goicoechea EL, Hernaiz PJ (1995) Forage yields and quality of common vetch and oat sown at varying seeding ratios and seeding rates of common vetch. Field Crop Res. 41(2): 135-140.

Carpita N, McCann M (2000) The cell wall. In: Buchanan, B.B., Gruissem, W., Jones, R.L. (Eds.), Biochemistry and molecular biology of plants. American Society of Plant Biologists, Maryland, USA, pp. 52-108.

Carr PM, Martin GB, Caton JS, Poland WW (1998). Forage and nitrogen yield of barley-pea and oat-pea intercrops. Agron J. 90(1): 79-84.

Dadson RB, Hashem FM, Javaid I, Joshi J, Allen AL, Devine TE (2005) Effect of water stress on the yield of cowpea (Vigna unguiculata $\mathrm{L}$. Walp.) genotypes in the Delmarva region of the United States. J Agron Crop Sci. 191(3): 210-217.

Dahmardeh M, Ghanbari A, Syasar B, Ramrodi M (2009) Intercropping maize (Zea mays L.) and cow pea (Vigna unguiculata L.) as a whole-crop forage: Effects of planting ratio and harvest time on forage yield and quality. J Food Agric Environ. 7(2): 505-509.

Ehlers JD, Hall AE (1997) Cowpea (Vigna unguiculata L. Walp.). Field Crop Res. 53:187-204.

El-Karamany MF, Elwea TA, Bakry BA (2012) Effect of mixture rates on forage mixture of Egyptian clover (Trifolium alexandrinum) with triticale ( $X$ triticosecale wittmack) under newly reclaimed sandy soil. Aust J Basic Appl Res. 6:40-44. 
El-Karamany MF, Bakry BA, Elewa TA (2014) Integrated action of mixture rates and nitrogen levels on quantity and quality of forage mixture from Egyptian clover and barley in sandy soil. Agric Sci. 5(14): 1539-1546.

El-Nahrawy M (2008a) Pasture and forage status in Egyptlimitations and opportunities. The $9^{\text {th }}$ International Conference on Dryland Development-Sustainable Development in Dryland; Meeting the Challenge of Global Climate Change, 2008, Alexandria, Egypt.

El-Nahrawy M (2008b) The vital role of Egyptian clover in Egyptian agriculture. The $9^{\text {th }}$ International Conference on Dryland Development-Sustainable Development in Dryland; Meeting the Challenge of Global Climate Change, 2008, Alexandria, Egypt.

Eskandari H (2012) Yield and quality of forage produced in intercropping of maize (Zea mays) with cowpea (Vigna sinensis) and mung bean (Vigna radiate) as double cropped. $\mathrm{J}$ Basic Appl Sci Res. 2(1): 93-97.

Ghanbari Bonjar A, Lee HC (2003) Intercropped wheat (Triticum aestivum) and bean (Vicia faba) as a whole-crop forage: Effect of harvest time on forage yield and quality. Grass and Forage Sci. 58(1): 28-36.

Giacomini SJ, Vendruseolo ERO, Cubilla M, Nicoloso RS, Fries MR (2003) Dry matter, C/N ratio and nitrogen, phosphorus and potassium accumulation in mixed soil cover crops in Southern Brazil. Rev Bras Cienc Solo. 27(2): 325-334.

Hancock DW (2011) Using relative forage quality to categorize hay. The University of Georgia. Cooperative Extension.

Hingra SH, Davis B, Akhtar MJA (1995) Fodder production. Food and Agriculture Organization of the United Nations. pp. 8.

Holland JB, Brummer EC (1999) Cultivar effects on oat-berseem clover intercrops. Agron J. 91(2): 321-329.

Ibrahim M, Rafiq M, Sultan A, Akram M, Gohar MA (2006) Green fodder yield and quality evaluation of maize and cowpea sown alone and in combination. J Agric Res. 44(1): 15-21.

Khan AG, Nadeem MA, Ali A, Bhatti MB (1987) Comparative efficiency of different varieties of cowpea for production and nutritive value under rainfed conditions. In Proceedings of $4^{\text {th }}$ AAAP Animal Science Congress. Hamilton, New Zealand, February 1-6. Pp. 324.

Laidlaw AS, Teuber N (2001) Temperate forage grass-legume mixtures: Advances and Perspectives. Proc. XIX International Grassland Congress, 11-21 February 2001. Sao Paulo, Brazil, 85-92.

Linn J, Kuehn C (1994) The effects of forage quality on performance and cost of feeding lactating dairy cows. University of Minnesota, Department of Animal Science. St. Paul, MN.

Lithourgidis AS, Vasilakoglou IB, Dhima KV, Dordas CA, Yiakoulaki MD (2006) Forage yield and quality of common vetch mixtures with oat and triticale in two seeding ratios. Field Crop Res. 99(2): 106-113.

Lynch DH, Voroney RP, Warman PR (2004) Nitrogen availability from composts for humid region perennial grass and legume-grass forage production. J Environ Qual. 33(4): 1509-1520.

Marsalis MA, Hagevoort GR, Lauriault LM (2009) Hay quality, sampling, and testing. New Mexico State University, USA. Circular 641, pp. 1-8

Moore JE, Undersander DJ (2002a) Relative forage quality: A proposal for replacement for relative feed value. Proceedings National Forage Testing Association.

Moore JE, Undersander DJ (2002b) Relative forage quality: An alternative to relative feed value and quality index. pp. 16-31. In: Proceedings $13^{\text {th }}$ Annual Florida Ruminant Nutrition Symposium. January 10-11, University of Florida, Gainesville.

Moreira N (1989) The effect of seed rate and nitrogen fertilizer on the nutritive value of oat-vetch mixtures. J Agric Sci Camb. 112(1): 57-66
Nor El-Din MA (1978) Effect of berseem-ryegrass mixtures on forage yield. M.Sc. Thesis, Faculty of Agriculture. Al-Azhar University.

NRC (2001) Nutrient Requirements of Beef Cattle, Seventh Revised Edition. National Research Council, National Academy Press, Washington, DC.

Oduor OA (2007) Cowpea seed quality in response to production site and water stress. Ph.D. Thesis, Kwa Zulu-Natal, Pietermaritzburg University. (URL: http://hdl.handle.net/ 10413/75).

Osman AE, Nersoyan N (1986) Effect of the proportion of species on the yield and quality of forage mixtures, and on the yield of barley in the following year. Exp Agr. 22(4): 345-351.

Paulson J, Jung H, Raeth-Knight M, Linn J (2008) Grass vs. legume forages for dairy cattle. Minnesota Nutrition Conference.

Rakeih N, Kayyal H, Larbi A, Habib N (2008) Forage potential of triticale in mixtures with forage legumes in rainfed regions (Second and third stability zones) in Syria. Tishreen University Journal for Research and Scientific Studies-Biological Sciences Series 30(5): 203-216.

Rohweder DA, Barnes RF, Jorgensen N (1978) Proposed hay grading standards based on laboratory analyses for evaluating quality. J Anim Sci. 47(3): 747-759.

Ross SM, King JR, O'Donovan JT, Spaner D (2004) Forage potential of intercropping berseem clover with barley, oat, or triticale. Agron J. 96(4): 1013-1020.

SADS (2009) Sustainable Agricultural Development Strategy Towards 2030. Agricultural Research and Development Council. Arab Republic of Egypt, Ministry of Agriculture and Land Reclamation. Oct. 2009.

SAS Institute, Inc. 2000. SAS/STAT User's Guide, Version 9.1 SAS Institute, Cary, NC.

Sengul S (2003) Performance of some forage grasses or legumes and their mixtures under dry land conditions. Eur J Agron. 19(3): 401-409.

Sleugh B, Moore KJ, George JR, Brummer EC (2000) Binary legume-grass mixtures improve forage yield, quality, and seasonal distribution. Agron J. 92(1): 24-29.

Steele WM (1972) Cowpea in Nigeria. PhD thesis, University of Reading, UK.

Van Soest PJ, Robertson JB, Lewis BA (1991) Methods for dietary fiber, neutral detergent fiber, and nonstarch polysaccharides in relation to animal nutrition. J Dairy Sci. 74(10): 3583-3597.

Waldo DR, Jorgensen NA (1981) Forages for high animal production: Nutritional factors and effects of conservation. J Dairy Sci. 64(6): 1207-1229.

Winer BJ (1971) Statistical principles in experimental design. $2^{\text {nd }}$ Edition. McGraw-Hill Kogakusha, LTD.

Zhang FS, Li L (2003) Using competitive and facilitative interactions in intercropping systems enhances crop productivity and nutrient-use efficiency. Plant Soil. 248(1-2): 305-312. 